\title{
Testicular regression syndrome
}

INSERM

\section{Source}

INSERM. (1999). Orphanet: an online rare disease and orphan drug data base. Testicular regression syndrome. ORPHA:983

Testicular regression syndrome (TRS) is a developmental anomaly characterized by the absence of one or both testicles with partial or complete absence of testicular tissue. TRS may vary from normal male with unilateral no-palpable testis through phenotypic male with micropenis, to phenotypic female. The phenotype depends on the extent and timing of the intrauterine accident in relation to sexual development. 